\title{
Prospective Study of Source Material for Spring Barley Breeding North-Western Region
}

\author{
Tatiana N. Radyukevich \\ Federal State Budget Institution \\ Leningrad research institute for \\ agricultural science «BELOGORKA» \\ Leningrad region, Gatchina district \\ Belogorka, Russian Federation,
}

Lyudmila I. Kartashea

Federal State Budget Institution

Leningrad research institute for agricultural science «BELOGORKA»

Leningrad region, Gatchina district,

Belogorka, Russian Federation

e-mail: lenniish@mail.ru

\author{
Lyubov M. Bondareva \\ Federal State Budget Institution \\ Leningrad research institute for \\ agricultural science «BELOGORKA» \\ Leningrad region, Gatchina district, \\ Belogorka, Russian Federation \\ e-mail: lenniish@mail.ru \\ Dmitry A. Danilov \\ Federal State Budget Institution \\ Leningrad research institute for \\ agricultural science «BELOGORKA» \\ Leningrad region, Gatchina district, \\ Belogorka, Russian Federation \\ e-mail: stown200@mail.ru
}

\begin{abstract}
The article presents the results of a 3-year study of the varieties from the world collection of the Federal Research Centre of the All-Russian Institute of Plant Genetic Resources named after N.I. Vavilov (VIR) in order to identify sources of economically valuable traits when using them in breeding work. Sources of precocity (6 varieties), of a short stalk (20 varieties), of a long tail ( 7 varieties), and sources of coarse grains (12 varieties) were identified, and the most harmful fungal diseases of the collection were identified. On the basis of the identified sources, a valuable initial selection material for spring barley is created at Leningrad Research Institute of Agriculture "BELOGORKA".
\end{abstract}

Keywords—barley, collection, breeding, speed, sustainability to diseases

\section{INTRODUCTION}

One of the main grain crops for feed production in Europe is spring barley. There are thousands of cultivated barley landraces and hundreds of cultivars. Cultivars can be classified according to several factors: the number of rows of grains (2row and 6-row), compactness of spikes, hull adherence (hulled or naked barley), presence or size of awns, growth habit and color $[12,17,20,22,24,25,30]$. The end-use may also be a way to classify barley. The average yield for barley grain is 2.7 t/ha, but there are large differences among countries starting from yields as high as $8.39 \mathrm{t} / \mathrm{ha}$ in Belgium and ending with yields as low as $0.6 \mathrm{t} / \mathrm{ha}$ in Morocco and $0.2 \mathrm{t} / \mathrm{ha}$ in Lesotho [31].

Barley grain has three major uses: livestock feed, raw material for alcohol and starch production, and food. Barley is of utmost importance for livestock feeding, which accounts for about $85 \%$ of barley production. Six-row barleys, which have higher protein content, are a valuable feed ingredient. Tworow barleys contain more starch and less protein and are thus preferred for brewing. Barley with more than $11.5 \%$ of protein causes beer cloudiness $[5,8,19]$.

A barley grain is used for the production of alcohol - beer whisky and ethanol, non-alcoholic beverages, barley tea, breakfast beverages. Food products include starch flour, flakes and pearled barley and it is a staple food in several countries including Morocco, India, China and Ethiopia [8,31]. The byproducts of barley grain processing are used as feed: brewer's grains, brewer's yeast, malt culms (barley sprouts and rootlets), barley distillers and solubles, hulls, bran and barley feed the by-product of pearl barley production. Barley forage can be fed to livestock as pasture, hay or silage. Barley straw is also used as fodder for ruminants and as bedding material.

Milk and meat cattle breeding are the main sectors of agricultural production in the North-West region of Russia. The basis for the development of animal breeding and poultry in the region is the creation of a stable high-quality feed base, which is largely formed by concentrated feeds. The basis of these feeds is a grain of local production. The use of own grain ensures a reduction in production costs and an increase in the competitiveness of animal breeding products, allows the use of modern technologies for the preparation of concentrated feeds, such as production of grain-haylage and grain crushing $[7,10]$. These advanced technologies are widely used in the areas of the North-West of the Russian Federation. For example, in the Leningrad region, about $15 \%$ of grain crops are harvested for grain-haylage, up to $50 \%$ - for production of crushed grains, and $15 \%$ for dry feed grains [15]. Cereals in the North-West 
region, in general, are grown for forage purposes. The spring barley is the most important forage culture for this area. The barley occupies $63 \%$ of the grain area, oats $-20 \%$, winter and spring wheat $-12 \%$, spring and winter triticale $-5 \%$ of the area in the Leningrad region [7].

At the present stage of the development of agriculture, the variety is the most effective and most accessible mean to increase the size and quality of the crop, energy saving, to increase the nutritional value and competitiveness of agricultural production.

The creation of new high-yielding varieties that meet the requirements of modern agricultural production is necessary for the development of the entire agro-industrial complex in Russia.

The purpose of this study is to identify genetic sources of economically valuable features for creation of a promising breeding material of spring barley on the basis of studying the collection varieties of the Federal Research Center of the AllRussian Institute of Plant Genetic Resources named after N.I. Vavilov (VIR)[18].

\section{MATERIALS AND METHOD}

A comprehensive study of varieties and samples of spring barley Hordeum vulgare of the VIR collection on economicvaluable traits was carried out within three years. 107 samples of spring barley were studied in 2015, 84 - in 2016, and 73 - in 2017.

The studied samples included zoned varieties both in the North-West region, and in other regions of Russia, varieties of domestic breeding and foreign countries. Most varieties of barley were varieties from Western Europe (Czech Republic, Germany, France, England), Belarus, Ukraine, the Baltic States (Latvia, Lithuania), Finland, Sweden, Denmark, as well as the USA and Australia [10,12,17,21,24,25]. In addition, varieties and promising breeding lines of the State research enterprise Leningrad research institute for applied agricultural science, Belogorka Russian (Leningrad RIAS «Belogorka»), such as Leningradskiy, Severyanin, Baltika, Murash, Belogorskiy, Karat, L1505, and L1623, were sown in the collection seed-field. Zoned and widely cultivated variety of spring barley Suzdalets was selected by the Agricultural Research Institute of the Central Regions of the NonChernozem Zone, and Lenigrandskiy variety was selected by the Leningrad RIAS «Belogorka», which has been zoned in the North-West region since 2009. They were taken as standard varieties. The study of varieties of spring barley on the basis of morphological and economic-biological features was carried out according to the "CMEA international classifier of Hordeum genus", "Methodological guidelines for studying and preserving the world collection of barley and oats" $[16,18]$.

\section{RESULTS OF STUDIES}

The main direction of breeding work in the Leningrad Research Institute of Agriculture "Belogorka" is breeding for the creation of productive and early-ripe barley varieties.

Barley varieties studied in the collection seed-field mainly belonged to the group of middle-ripe. According to the data for 3 years, 6 early-ripe varieties were identified, among them the majority ( 5 varieties) are of Russian breeding, including 4 varieties bred by Leningrad Research Institute "Belogorka" (Leningradskiy, Murash, Belogorskiy, and L1505), Tarskii 3 (Omsk region) and a Unari variety of foreign breeding (Finland). The fastest-growing variety of the studied ones was standard variety Leningradskiy (duration of the vegetation period was 79 days, and for standard variety Suzdalets - 88 days according to average data for 3 years) (Table 1). One of the limiting factors for increasing yields in conditions of increased moisture and long daylight is lodging. The lodging leads to a loss of 10 to $50 \%$ of the crop, prevents mechanized harvesting, impairs the quality of grain and seeds $[1,2,11,13,14,23,28]$. The resistance to lodging in cereals is closely related to the height and strength of the straw. Shortstemmed plants, as a rule, are more resistant to lodging According to the results of a 3-year study of collection samples, 20 low-growing varieties $(61-70 \mathrm{~cm}$ long) and medium-sized $(71-80 \mathrm{~cm})$ varieties were identified. These varieties are shorter-stemmed than early-ripe variety Leningradskiy, which is prone to lodging in wet years (the length of the straw is $92 \mathrm{~cm}$ ) (Table 2).

TABLE I. SOURCES OF THE SPRING BARLEY EARLY RIPENESS

\begin{tabular}{|c|l|l|c|c|c|c|}
\hline \multirow{2}{*}{$\begin{array}{c}\text { VIR } \\
\text { catalogue } \\
\text { No. }\end{array}$} & \multicolumn{1}{|c|}{$\begin{array}{c}\text { Variety } \\
\text { sample }\end{array}$} & \multicolumn{2}{|c|}{ Origin } & \multicolumn{3}{|c|}{ Vegetation period, days } \\
\cline { 4 - 7 } & & & 2015 & 2016 & 2017 & average \\
\hline 30314 & $\begin{array}{l}\text { Suzdalets, st. } \\
\text { (nutans) }\end{array}$ & $\begin{array}{l}\text { Russia, } \\
\text { Moscow } \\
\text { region }\end{array}$ & 86 & 83 & 94 & 88 \\
\hline 30975 & $\begin{array}{l}\text { Leningradskiy } \\
\text { st. pallidum }\end{array}$ & $\begin{array}{l}\text { Russia, } \\
\text { Leningrad } \\
\text { region }\end{array}$ & 78 & 71 & 88 & 79 \\
\hline 30593 & $\begin{array}{l}\text { Tarski } \\
\text { (pallidum) }\end{array}$ & $\begin{array}{l}\text { Russia, } \\
\text { Omsk } \\
\text { region }\end{array}$ & 79 & 76 & 90 & 82 \\
\hline 22089 & $\begin{array}{l}\text { Murash } \\
\text { (pallidum) }\end{array}$ & $\begin{array}{l}\text { Russia, } \\
\text { Leningrad } \\
\text { region }\end{array}$ & 79 & 75 & 92 & 82 \\
\hline 30457 & $\begin{array}{l}\text { Belogorskiy } \\
\text { (pall.+ricot) }\end{array}$ & $\begin{array}{l}\text { Russia, } \\
\text { Leningrad } \\
\text { region }\end{array}$ & 81 & 75 & 91 & 82 \\
\hline & $\begin{array}{l}\text { L1505 } \\
\text { (pallidum) }\end{array}$ & $\begin{array}{l}\text { Finland } \\
\text { Leningrad } \\
\text { region }\end{array}$ & 81 & 79 & 92 & 84 \\
\hline
\end{tabular}


TABLE II. SOURCES OF SHORT-STALK SPRING BARLEY

\begin{tabular}{|c|c|c|c|c|c|c|}
\hline \multirow{2}{*}{$\begin{array}{l}\text { VIR } \\
\text { catalogue } \\
\text { No. } \\
\end{array}$} & \multirow{2}{*}{$\begin{array}{l}\text { Variety } \\
\text { sample }\end{array}$} & \multirow{2}{*}{ Origin } & \multicolumn{4}{|c|}{ Height of a stem, cm } \\
\hline & & & 2015 & 2016 & 2017 & aver. \\
\hline \multicolumn{7}{|c|}{ Species pallidum } \\
\hline 30975 & $\begin{array}{l}\text { Leningradskiy } \\
\text { st. }\end{array}$ & $\begin{array}{l}\text { Russia, } \\
\text { Leningrad } \\
\text { region }\end{array}$ & 101 & 78 & 97 & 92.0 \\
\hline & L1007-99 & Kirov & 68 & 67 & 80 & 71.5 \\
\hline \multicolumn{7}{|c|}{ Species } \\
\hline 30314 & Suzdalets st. & $\begin{array}{l}\text { Russia, } \\
\text { Moscow } \\
\text { region }\end{array}$ & 93 & 79 & 85 & 85.7 \\
\hline 31246 & Brovar & Belarus & 76 & 74 & 80 & 76.6 \\
\hline 31241 & Quench & \multirow{2}{*}{ Denmark } & 67 & 70 & 75 & 70.7 \\
\hline 31244 & Anakin & & 77 & 75 & 80 & 77.4 \\
\hline 31242 & J.B. Flavour & \multirow{3}{*}{ Germany } & 74 & 69 & 71 & 71.3 \\
\hline 31245 & Posada & & 73 & 69 & 75 & 72.3 \\
\hline 31192 & Jenuva & & 79 & 77 & 74 & 76.7 \\
\hline 31179 & Radegast & \multirow{6}{*}{$\begin{array}{l}\text { Czech } \\
\text { Republic }\end{array}$} & 78 & 72 & 75 & 75.0 \\
\hline 31181 & Pedant & & 77 & 73 & 80 & 76.7 \\
\hline 31183 & Malz & & 71 & 72 & 69 & 70.6 \\
\hline 31184 & Ebson & & 79 & 71 & 73 & 74.3 \\
\hline 31186 & Respect & & 74 & 67 & 76 & 72.4 \\
\hline 30943 & Amulet & & 73 & 63 & 79 & 71.6 \\
\hline 31206 & Arbalet & Finland & 74 & 68 & 78 & 73.3 \\
\hline 31249 & Eifel & \multirow{3}{*}{ France } & 68 & 63 & 76 & 69.0 \\
\hline 31250 & Pionier & & 73 & 65 & 75 & 71.0 \\
\hline 31296 & Olimpic & & 71 & 68 & 71 & 70.0 \\
\hline 31287 & April & $\begin{array}{l}\text { Russia, } \\
\text { Finland } \\
\end{array}$ & 79 & 76 & 80 & 78.3 \\
\hline 31297 & Cherio & Denmark & 73 & 77 & 80 & 76.7 \\
\hline 30966 & Margret & Germany & 74 & 79 & 79 & 77.3 \\
\hline
\end{tabular}

During the study years, the weather during the plumpness and ripening period was rainy and windy. Excessive moistening facilitated the lodging of plants in the plots. Thus, in 2015,15 samples out of $107(68 \%)$ were resistant to lodging (stability assessment - 7-9 points), in $2016-23$ samples out of $84(27.3 \%)$ and in $2017-25$ samples out of 73 $(34,2 \%)$ (Table 3). The length of the ear is one of the features that determines the productivity of barley plants. According to the International Classification of Barley Selection Characteristics (1983), most of the varieties under study belong to the group with an average length of the ear (7.1-9.0, 9.1-10.0 cm). A long ear $(10.1-11.0,11.1-12.0 \mathrm{~cm})$ was noted in varieties of Russian breeding Karat and Vladimir. Standard varieties Suzdalets have the length of the ear of $8.6 \mathrm{~cm}$, and variety Leningradskiy $-7.3 \mathrm{~cm}$ (Table 4 ).

The mass of 1000 grains is a feature that determines the yield of a variety.

Weather conditions during the study years (moderately warm weather, sufficient rainfall) contributed to the formation of large grains in barley plants. A very high mass of 1000 grains was noted in varieties Jdumeja (Latvia), Unari (Finland), Amulet (Czech Republic), Vladimir (Russia) and Eifel (France) (table 5).
The evaluation of barley varieties for resistance to the most harmful fungal diseases is of great importance. In recent years, the severity of leaf parasites such as powdery mildew (mushroom Blumeria graminis (DC), net (Pyrenophora teres (Died.)) Drechler and dark-brown (Bipolaris Sorokiniana (Sacc.) Shoemaker blotches. The certain epiphytoties occur at a frequency of once every 3-5 years, while crop losses can reach $25-50 \%$ in susceptible varieties $[1,2,6,8]$.

TABLE III. RESISTANCE OF COLLECTION SAMPLES OF BARLEY TO LODGING

\begin{tabular}{|c|c|c|c|}
\hline \multirow{2}{*}{$\begin{array}{c}\text { Year of } \\
\text { study }\end{array}$} & $\begin{array}{c}\text { Number } \\
\text { of studied samples }\end{array}$ & \multicolumn{2}{|c|}{$\begin{array}{c}\text { Samples resistant to lodging } \\
\text { (score 7-9 points) }\end{array}$} \\
\cline { 3 - 4 } & 107 & Number & $\%$ \\
\hline 2015 & 84 & 15 & 14 \\
\hline 2016 & 73 & 23 & 27.3 \\
\hline 2017 & 25 & 34.2 \\
\hline
\end{tabular}

TABLE IV. SOURCES OF LONG EAR IN SPRING BARLEY

\begin{tabular}{|c|c|c|c|c|c|c|}
\hline \multirow{2}{*}{$\begin{array}{c}\text { VIR } \\
\text { catalogue } \\
\text { No. }\end{array}$} & \multirow{2}{*}{$\begin{array}{l}\text { Variety } \\
\text { sample }\end{array}$} & \multirow{2}{*}{ Origin } & \multicolumn{4}{|c|}{ Length of ear, cm } \\
\hline & & & 2015 & 2016 & 2017 & aver. \\
\hline 30314 & Suzdalets, st. & $\begin{array}{l}\text { Russia, } \\
\text { Moscow } \\
\text { region }\end{array}$ & 9 & 8 & 9 & 8.6 \\
\hline 30975 & $\begin{array}{l}\text { Leningradskiy } \\
\text { st. }\end{array}$ & \multirow{4}{*}{$\begin{array}{l}\text { Russia, } \\
\text { Leningrad } \\
\text { region }\end{array}$} & 8 & 7 & 7 & 7.3 \\
\hline 30974 & Severyanin & & 10 & 9 & 9 & 9.4 \\
\hline 30589 & Baltika & & 10 & 8 & 10 & 9.4 \\
\hline 31196 & Karat & & 11 & 10 & 11 & 10.7 \\
\hline 30844 & Hadzhibey & $\begin{array}{l}\text { Russia, } \\
\text { Belgorod } \\
\text { region }\end{array}$ & 9 & 10 & 10 & 9.7 \\
\hline 30981 & Vladimir & $\begin{array}{l}\text { Russia, } \\
\text { Moscow } \\
\text { region }\end{array}$ & 10 & 10 & 11 & 10.4 \\
\hline 31297 & Cherio & Denmark & 10 & 9 & 9 & 9.4 \\
\hline 31288 & Avtograf & $\begin{array}{l}\text { Russia, } \\
\text { Finland }\end{array}$ & 9 & 9 & 10 & 9.4 \\
\hline
\end{tabular}

The mass of 1000 grains is a feature that determines the yield of a variety. Weather conditions during the study years (moderately warm weather, sufficient rainfall) contributed to the for-mation of large grains in barley plants. A very high mass of 1000 grains was noted in the varieties Jdumeja (Latvia), Unari (Finland), Amulet (Czech Republic), Vladimir (Russia) and Eifel (France) (table 5).

The evaluation of barley varieties for resistance to the most harmful fungal diseases is of great importance. In recent years, the severity of leaf parasites such as powdery mildew (mushroom Blumeria graminis (DC), net (Pyrenophora teres (Died.)) Drechler and dark-brown (Bipolaris Sorokiniana (Sacc.) Shoemaker blotches has been studied. Certain epiphytoties occur at a frequency of once every 3-5 years, 
while crop losses can reach $25-50 \%$ in susceptible varieties $[1,2,6,9]$

TABLE V. SOURCES OF LARGE GRAIN IN SPRING BARLEY

\begin{tabular}{|c|c|c|c|c|c|c|}
\hline \multirow[b]{2}{*}{$\begin{array}{c}\text { VIR } \\
\text { catalogue } \\
\text { No. }\end{array}$} & \multirow[b]{2}{*}{$\begin{array}{l}\text { Variety } \\
\text { sample }\end{array}$} & \multirow[b]{2}{*}{ Origin } & \multicolumn{4}{|c|}{ Weight of 1000 grains } \\
\hline & & & $\stackrel{n}{\frac{n}{2}}$ & $\frac{b}{2}$ & 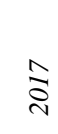 & $\begin{array}{l}0 \\
0 \\
0 \\
0 \\
0 \\
0\end{array}$ \\
\hline 30314 & Suzdalets, st. & $\begin{array}{l}\text { Russia, } \\
\text { Moscow } \\
\text { region }\end{array}$ & 60.5 & 41.5 & 54.2 & 52.0 \\
\hline 30975 & $\begin{array}{l}\text { Leningradskiy } \\
\text { st. }\end{array}$ & $\begin{array}{l}\text { Russia, } \\
\text { Leningrad } \\
\text { region }\end{array}$ & 47.3 & 35.6 & 44.1 & 42.3 \\
\hline 30591 & Rahat & $\begin{array}{l}\text { Russia, } \\
\text { Moscow } \\
\text { region }\end{array}$ & 63.3 & 50.8 & 58.2 & 57.4 \\
\hline 30457 & Unari & Finland & 67.5 & 53.5 & 57.3 & 59.4 \\
\hline 30844 & Hadzhibey & $\begin{array}{l}\text { Russia, } \\
\text { Belgorod } \\
\text { region }\end{array}$ & 65.3 & 46.0 & 53.4 & 54.9 \\
\hline & L1623 & $\begin{array}{l}\text { Russia, } \\
\text { Leningrad } \\
\text { region }\end{array}$ & 63.4 & 50.4 & 54.1 & 55.9 \\
\hline 30922 & Jdumeja & Latvia & 68.8 & 55.3 & 62.5 & 62.2 \\
\hline 30943 & Amulet & $\begin{array}{l}\text { Czech } \\
\text { Republic }\end{array}$ & 63.2 & 53.8 & 62.3 & 59.8 \\
\hline 30966 & Margret & Germany & 62.5 & 47.8 & 55.2 & 55.1 \\
\hline 30981 & Vladimir & $\begin{array}{l}\text { Russia, } \\
\text { Moscow } \\
\text { region }\end{array}$ & 65.5 & 57.0 & 54.6 & 59.0 \\
\hline 31244 & Anakin & Denmark & 65.7 & 52.8 & 55.4 & 57.9 \\
\hline 31249 & Eifel & France & 67.0 & 50.4 & 59.6 & 59.0 \\
\hline 31250 & Pionier & France & 67.2 & 45.6 & 63.8 & 58.8 \\
\hline 30974 & Severyanin & $\begin{array}{l}\text { Russia, } \\
\text { Leningrad } \\
\text { region }\end{array}$ & 60.5 & 51.8 & 49.6 & 53.9 \\
\hline
\end{tabular}

According to the agreement on scientific cooperation with the laboratory for study of immunity of plants to diseases of the All-Russian Plant Protection Institute (city of Pushkin), the staff of this laboratory annually assess the varieties of spring barley of the collection seed-field for resistance to leaf blotches.
No varieties immune to the net and dark brown blotches were identified during the study of collection crops of the spring barley during the period $2015-2017.76 .7 \%$ to $96.2 \%$ of barley samples were characterized by years by the weak lesion (up to $15 \%$ ) to the net blotch agent, and 14.3 to $93.4 \%$ - to the dark-brown blotch (table.6).

In 2016, in the North-West region of the Russian Federation, including in the Leningrad Region, an epiphytoty of dark brown blotch was observed. The lesion of standard varieties Leningradskiy and Suzdalets was 30-50\%. The varieties Xanadou, Jenuva, Mauritia (Germany), Malz, Respect (Czech Republic) were characterized by high susceptibility $(50-70 \%)$ to the pathogen. Against this background, variety Malva (Latvia) was noted; its lesion in the epiphytoty year was $10-15 \%$.

In 2015, the abundance of precipitation under a favorable temperature regime contributed to the epiphytotic development of powdery mildew. The pathogen development was $40-50 \%$ on standard varieties. The lesion above the standards $(60-80 \%)$ was noted in varieties Zenit, Zauralsky 1 , Rodnik Prikamye, Variant, Sibiryak, Stepan, Moscovskiy 86 (Russia), Romantik (Ukraine), Saloon (Czech Republic).

TABLE VI. EVALUATION OF SPRING BARLEY VARIETIES FOR RESISTANCE TO LEAF BLOTCHES

\begin{tabular}{|c|c|c|c|c|c|c|c|c|c|}
\hline \multirow[b]{3}{*}{ 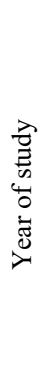 } & \multirow{3}{*}{ 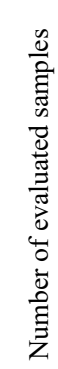 } & \multicolumn{8}{|c|}{ Development of disease, $\%$} \\
\hline & & \multicolumn{4}{|c|}{ net blotch } & \multicolumn{4}{|c|}{ dark brown blotch } \\
\hline & & $\begin{array}{l}\stackrel{\circ}{i} \\
\stackrel{\circ}{0} \\
\stackrel{2}{3}\end{array}$ & 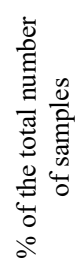 & 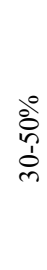 & 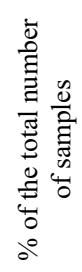 & $\begin{array}{l}\text { i̊ } \\
\text { i̊ } \\
\text { ㅇ }\end{array}$ & 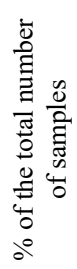 & 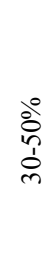 & 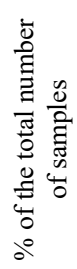 \\
\hline$\frac{n}{\stackrel{n}{c}}$ & 107 & 103 & 96.2 & 4 & 3.8 & 100 & 93.4 & 7 & 6.6 \\
\hline$\stackrel{0}{\stackrel{0}{0}}$ & 84 & 70 & 83.4 & 14 & 16.6 & 12 & 14.3 & 72 & 85.7 \\
\hline$\stackrel{\bar{\partial}}{\circ}$ & 73 & 56 & 76.7 & 17 & 23.3 & 35 & 47.9 & 38 & 52.1 \\
\hline
\end{tabular}

\section{CONCLUSION}

As a result of the studies, sources of valuable economic features were identified. The hybridization is annually carried out in the laboratory with active involvement of dedicated sources to create a new promising breeding material. The scope of hybridization is $25-30$ of crossing combinations, and the binding of hybrid grains is $\mathrm{F}_{0}-46.2$ to $82.3 \%$. The involvement in the selection process of seed sources with economically valuable traits will allow one to get varieties of spring barley with guaranteed yield. 


\section{References}

[1] Y. Anbessa, P. Juskiw, A. Good, J. Nyachiro, J. Helm, "Genetic variability in nitrogen use efficiency of spring barley", Crop Science vol. 49, 2009, 1259-1269.

[2] O.S. Afanasenko, "The role of A.Ya. Trofimovskaya in the development of research on the immunolog-ical characteristics of barley from the genetic centers of evolution", Proceedings of Applied Botany, Genetics and Breeding, Vol. 165, St. Petersburg, 2009, pp.8-12. (In Russian).

[3] G. Backes, B. Hatz, A. Jahoor, G. Fischbeck, "RFLP diversity within and between major groups of barley in Europe", Plant Breed, vol. 122(4), 2003, pp.291-299.

[4] N-O. Bertholdsson, A. Kolodinska-Brantestam, "A century of Nordic barley breeding - effects on early vigour root and shoot growth, straw length, harvest index and grain weight", European Journal of Agronomy vol. 30,2009

[5] J. Z. Czembor, "Resistance to powdery mildew in barley (Hordeum vulgare L.) landraces from Egypt", PGRNewsletter, vol. 123, 2010, pp. $52-60$.

[6] T.A.Danilova, S.M. Sinitsyna, "Prospects for the development of the grain industry in the North-West Federal District of the Russian Federation", In Proceedings of the International Agro-Industrial Congress, St. Petersburg: «Expoforum», 2013, pp. 155-156. (In Russian) [Prospects for the Development of the Russian Agro-Industrial Complex in the Conditions of WTO Membership, 2013]

[7] W. Friedt, R.D. Horsley, B.L. Harvey, D.M.E. Poulsen, R.C.M. Lance, S. Ceccarelli, S. Grando, F. Capettini, Barley breeding history, progress, objectives, and technology, Wiley Blackwell: Oxford, 2011, doi 10.1002/9780470958636.ch8

[8] E.E. Geshele, Methodological guidelines on the phytopathological assessment of grain crop, Odessa: "VSGEB», 1971, p. 180 (In Russian).

[9] M. S. Hovmøller, V. Caffier, M. Jalli, et al, "The European barley powdery mildew virulence survey and disease nursery in 1993-1999", Agronomie, vol. 20 (7), 2000, pp. 729-743.

[10] M.V. Ivanov, N.V. Ivanova, "Varieties of spring barley for the NorthWest of Russia", Works on applied botany, genetics and selection, vol 162, St. Petersburg, pp. 78-83. (In Russian).

[11] A. Kokina, L. Legzdina, I. Berzina, M. Bleidere, I. Rashal, N. Rostoks, "Molecular marker based characterization of barley powdery mildew Mlo resistance locus in European varieties and breeding lines", Latvian Jornal of Agronomy, 2008, pp. 77.

[12] O.N. Kovaleva, N.N. Ivanova, "A new source material for barley breeding in the North-West of Russia", Proceedings on Applied Botany, Genetics and Selection, vol 171, 2013, pp. 284-286. (In Russian)

[13] V.M. Kovalev, K.A. Kosareva, "Falling of grain crops and the practice of applying retardants", Agricultural Biology, no. 8, 1990, pp. 72-81. (In Russian).

[14] V.A.Lapshuk, G.V. Vasyaev, "Problems of the grain market in the North-West region of Russia" Proceedings of Applied Botany, Genetics and Breeding, vol. 165, 2009, pp.157-160. (In Russian).

[15] Ya. Lekesh, I. Bares, A. Foral, et al, International Classifier of the Hardeum, Leningrad, 1983, p. 50 (In Russian).
[16] M. Lillemo, L. Reitan, Å. Bjørnstad, "Increasing impact of plant breeding on barley yields in central Norway from 1946 to 2008", Plant Breeding, vol. 129, 2010, pp. 484-490.

[17] I.G. Loskutov, Methodical guidelines for studying and preserving the world collection of barley and oats, St. Petersburg: N.I.Vavilov Research Institute of Plant Industry, 2012, p. 63 (In Russian).

[18] L. Malysheva-Otto, M.W. Ganal, J.R. Law, et al, Mol Breeding, vol. 20, 2007, p. 309, retrieved from: https://doi.org/10.1007/s11032-007-9093-y

[19] M. Muñoz-Amatriaín, A. Cuesta-Marcos, J.B. Endelman, J. Comadran, J.M.Bonman, H.E. Bockelman, et al, "The USDA barley core collection: genetic diversity, population structure, and potential for genome-wide association studies", PLoS One, vol. 9(4), 2014, pp. 1-13, doi: 10.1371/journal.pone.0094688

[20] M.-R. Naghavi, V. Mohammadi, M.-R. Ghannadha, "Gene number and heredity of barley powdery mil-dew (Erysiphe graminis f. sp. hordei) resistance at adult plant stage", International Journal of Agriculture and Biolo-gy, vol. 9 (2), 2007, pp. 239-241.

[21] N. Neykov, T. Mokreva, "Yield and coefficient of ecological valence of spring barley in the regions of Sadovo and Karnobat", Bulgaria Agricultural science and technology, vol.10, No. 1, 2018, pp. 8 - 11, doi: 10.15547/ast.2018.01.002

[22] V.F. Peresypkin, Diseases of grain crop, Moscow: Kolos, 1979, p. 279 (In Russian).

[23] N. Przulj, V. Momcilovic, "Dry matter and nitrogen accumulation and use in spring barley", Plant Soil and Environment, vol. 49, 2003, pp. 3647.

[24] A. Rajala, P. Peltonen-Sainio, M. Jalli, L. Jauhiainen, "One century of Nordic barley breeding: nitrogen use efficiency, agronomic traits and genetic diversity", Journal of Agricultural Science, vol.155, no. 4, 2017, pp. $582-598$

[25] A.H. Sallam, J.B. Endelman, J.L. Jannink, K.P. Smith, “Assessing genomic selection prediction accuracy in a dynamic barley breeding population", Plant Genome, vol. 8(1), 2015, doi: 10.3835/plantgenome

[26] K. Schmid, P. Thorwarth, Genomic selection in barley breeding, vol. 69, 2014, Springer, Berlin, pp 367-378. doi: 10.1007/978-3-662-44406

[27] L.G. Tyryshkin, N.S. Manaenko, I.A. Terentyeva, O.P. Kovaleva, Stability of collection samples of spring barley for powdery mildew, Proceedings of Applied Botany, Genetics and Selection, vol. 165, 2009, pp. 220-221. (In Russian)

[28] P. Thorwarth, J. Ahlemeyer, A.M. Bochard et al, Theor. Appl. Genet., vol. 130, 2017, art. 1669, doi:10.1007/s00122-017-2917-1

[29] A. Tondelli, X. Xu, M. Moragues, R. Sharma, F Schnaithmann, C. Ingvardsen et al, "Structural and temporal variation in genetic diversity of European spring two-row barley cultivars and association mapping of quantitative traits", Plant Genome, vol. 6, 2013, pp. 1-14, doi: 10.3835/plantgenome2013.03.0007

[30] Food And Agricultiral Ogranization Statistical department, 2011, retrieved from: http://faostat.fao.org/default.aspx 